IRSH 46 (200I), Supplement, pp. I7I-I 84 DOI: I0.I0I7/S002085900I000360

(C) 200 I Internationaal Instituut voor Sociale Geschiedenis

\title{
The Image of Jews in Byelorussia: Petitions as a Source for Popular Consciousness in the Early Twentieth Century
}

\author{
OLEG G. BuKHOVETS
}

The disintegration of the USSR, and of the communist system, in the last decade of the twentieth century, the rekindling of ethnic strife, and scholarly research into nationalism - all have renewed interest in the images that different ethnic and religious groups in eastern Europe have had of each other. In this context, the image of Jewishness has been of particular importance, both in political science and in history. An adequate analysis of ideas about Jewishness requires access to numerous mass sources. However, the number of sources available for this kind of enquiry is limited, compared, for instance, to the sources open for traditional Hebrew studies. This is especially true when we speak about the periods of autocracy and dictatorship. Both the Russian Empire and the USSR had besides periods of overt anti-Semitism - a tradition of hidden antiSemitism. The hidden and unofficial nature of this prejudice would not allow for mass opinion polls on anti-Semitism before the fall of the USSR. ${ }^{\mathrm{I}}$

In the absence of other sources, the research presented here focuses on a well-known source of information on mass consciousness in the history of modern Russia and other Commonwealth of Independent States (CIS) countries, namely petitions. In St Petersburg and other CIS cities, the archives hold collections of petitions from all social strata, addressed to state bodies, newspapers, political parties and other organizations, and similar documents which express opinions: petitions (nakazi) of the electorate to the candidates running for the State Duma, sentences (prigovori) of meetings of peasants and the urban lower middle classes, resolutions of meetings and congresses. ${ }^{2}$

I. See, for example: L. Gudkov and A. Levinson, "Otnosheniya naseleniya SSSR k evreyam”, Vestnik evrejskogo universiteta $v$ Moskve, I (1992), pp. 6-4I; "Izmenenija v otnoshenii k evrejam naselenija respublik na territorii byvshego SSSR", Vestnik evrejskogo universiteta v Moskve, 4 (1993), pp. 4-39; Ju S. Ermolaev, V.N. Karbalevich and V.N. Lomako, Razvitie belorusskoj natsii. Anketa respublicanskogo oprosa. (Minsk, 1992), pp. 5, I3-I 5.

2. O.G. Bukhovets, Sotsial'nye konflicty I krestianskaja mentalnost v Rossijskoj imperii 20 veka: novye materially, metody, resultaty (Moscow, I996), pp. 63-79; idem, "Patterns of the Peasants' Political History in the Years of the 1905-1907 Russian Revolution", Historical Social Research, I6 (199I), pp. 60-73; idem, "The Political Consciousness of Russian Peasantry in the Revolution 
Petitions were written in large numbers in the course of such major European upheavals as the French Revolution or the Revolution of I 848/ 49 in Germany. A number of them were submitted after the February Revolution in Russia in 1917. In I989, while the First Congress of People's Deputies of the USSR was in session, it received some 300,000 letters and telegrams. A. de Tocqueville qualified the petitions of 1789 as "documents unique in history". " Historians of these and other upheavals have used petitions to monitor changes in public opinion. ${ }^{4}$

Soviet historical studies give a good example of how great the distance can be between what potentially can be derived from a source, the information that is consciously accepted by scholars, and, finally, the information that is extracted from them in reality. What the rigid system of ideological and methodological coordinates of Soviet political science would not recognize as topical and important was not recognized in the sources. That is why, although the petitions were analysed thoroughly in the Soviet period, this analysis was narrow and selective. The interest in petitions of the 1905-1907 and I9I7 periods was mostly limited to the information on socioeconomic and political demands of peasants. ${ }^{5}$ The emphasis was on "correct" elements of those demands, namely, those that corresponded to the views of Lenin, and the programme and tactics of the Bolshevik party. It will be clear that the potential value of a document is not exhausted by this kind of analysis. Numerous details in the documents, which reflect the concrete historical spectrum of social reality, were never explored in the historiography.

A less biased analysis of these petitions shows that they can, among other things, provide information on the attitude of the different nationalities, ethnic, and religious groups of the Russian Empire towards each other. This enables us to restore the images held of the typical German, Pole, Russian, Jew, or Catholic. ${ }^{6}$

That such possibilities were missed cannot be wholly attributed to the

of 1905-1907: Sources, Methods and Some Results”, in M. Rothstein and D. Field (eds), Quantitative Methods in Agrarian History (Ames, 1993), pp. 209-226. The patriarchal nature of early twentieth-century Russian society vividly reveals itself in the fact that in all cases discussed here only males are considered.

3. A. de Tocqueville, Staryj porjadok i revolutsiya (Petrograd, I91 8), p. 4.

4. François-Xavier Coquin and Céline Gervais-Francelle (eds), I905. La première révolution Russe (Paris, 1986), pp. I8 I-202; E. Champion Franciya nakanune revolutcii po nakazam 1789 goda (St Petersburg, I 906); H. Best "Analysis of Content and Context of Historical Documents. The case of Petitions to the Frankfurt National Assembly i 848/49", Historic Social Research, 4 (1980), pp. 244-266; E.A. Lukitskij "Krestianskie nakazy o zemle", Istochnikovedenie istorii sovetskogo obtshestva, II (I968), pp. II 3, II4, II7, I6I and others.

5. Bukhovets, Sotsial'nye konflicty, pp. I 17-136, and others.

6. Based on 4,000 of these documents, collected in dozens of central and local archives in Russia and other CIS countries; ibid. pp. 79-89. 
imperatives of a dogmatic paradigm. However reductive the Soviet paradigm was, there were also more technical reasons, caused by the nature of the source itself. It is characterized by a very high density of information, even within individual documents. Furthermore, to derive additional information, the documents have to be analysed in series. Therefore, a method has been devised to extract information from the documents for further, formal analysis at a later stage. ${ }^{7}$

\section{ATTITUDES TOW ARDS JEWISHNESS}

It seems opportune to analyse the information enclosed in petitions on the image of Jews, especially because the Revolution of 1905-1907 brought the issue of Jewishness to the fore. Even an initial analysis of the petitions concerned shows that the information that can be gleaned from them is, in essence, new. Even within the different territorial units of the Jewish Pale, we can see important differences in popular anti-Semitism. Byelorussia is an attractive area for this analysis. It is a substantial region of the European part of the Russian Empire. At the beginning of the twentieth century, Is per cent of the population living within the present-day boundaries of the Republic of Byelorussia was Jewish. ${ }^{8}$ This was four times the proportion of Jews in the general population of the country, and twice the proportion in the Ukraine, which was considered a "Jewish" region. The Jewish presence in industry and trade, on the labour market and in land leasing, among craftsmen, and in other spheres of daily life, was quite substantial. In Byelorussia, Jews made up 54 per cent of the urban population and owned half of all factories and plants. Half the intellectuals were Jewish, and even 84.5 per cent of the merchants. ${ }^{9}$ This large Jewish presence makes Byelorussia an excellent candidate for an analysis of popular ideas on Jewishness.

For this analysis, 662 Byelorussian petitions connected with the I905I 907 Revolution were analysed. ${ }^{\circ}$ These dealt with numerous topics. The

7. See the literature mentioned in note 2.

8. The share of the Jewish population in the five Byelorussian goubernii (non-Byelorussian ouyezds included) is a little lower: I 3.8 per cent; Narysy Gistopyi Belarusi u $2-b$ chastkah, ch. I (Minsk, 1994), p. 333.

9. Z. V. Shybeka Garady Belarusi 60 gady (Minsk, 1997), pp. 260, 265; Narysy Gistoryi Belarusi, ch. I, p. 34I.

I0. Out of 673 petitions identified. Most of these were found in is funds of the Russian State Historic Archive (RGIA) in St. Peterburg. Others came from the State Archive of the Russian Federation (GARF) and the national archives of Byelorussia, Lithuania and the Ukraine, out of document collections and other publications. The complex of petitions under consideration covers 37 districts (ouyezds) of the Vilnyus, Viitebsk, Grodno, Minsk and Mogilyev regions (gouibernii) that are included in the present-day territory of Byelorussia and the Byelorussian party of the Novoaleksandrovsk district of the Koven region. An important share of the petitions comes not from separate villages but from groups of villages. More than a roo documents were 
200 petitions of the Samara and Voronej regions alone discussed 177 different topics, I I 3 of which were mentioned in three or more petitions. ${ }^{\text {II }}$ However, only 69 documents (or I0.4 per cent) touched upon, or mentioned, Jewishness. This is an important result by itself. That 90 per cent of the petitions are indifferent to the Jewish subject is not due to any special characteristic of the source. Petitions as a source were not "deaf". They could "hear" very well, but only when there was something to register. Percentages like these reflect the mentality of the authors of petitions and this allows us to draw relevant conclusions from the analysis that follows.

The 69 petitions that do mention Jewishness, do not differ in other aspects from the petitions that are indifferent to the subject. Still, given the Jewish presence in Byelorussia, the authors of these others petitions must have had contacts with Jews as well.

Let us take as an example the petition of the peasants of the villages Mouudriki, Guirino, Kletchino, and Aksanovks of the Vitebsk district, dated June 1906. It is addressed to the State Duma of Russia. The authors of the petition complain that their interests are neglected by merchants who cut down wood. These merchants' names are quoted as Mendel' Rarbinovitch, Shaya Shmerlin, and others. Nowhere in the nine-page-long petition is it mentioned that the merchants in question were Jewish. The same applies to an earlier petition to the Minister of Land Cultivation and State Property. ${ }^{\mathrm{I}}$

Different approaches to Jewishness are visible in the petitions of peasants from neighbouring villages. The petitions of the Ozer'ye and Tcherepy villages, of the small rural district (volost) of Nutchiporovitch in the Mogilyev region, are dated on the same day, i9 January 1906, and deal with the same issue, namely the refusal of Ms Krivosheina to sell a part of her woods. The peasants from Tcherepy accuse the land owner of preferring to deal with Jewish timber traders, but the inhabitants of the other village never mention this. ${ }^{13}$ The same can be said of the petitions of the neighbouring villages of the Oloutsha oblast in the Brest district, written in March-April 1906. ${ }^{\mathrm{I}}$ These examples show that the petitions lend themselves to an analysis of subtle differences in opinion between groups of people in a similar position.

approved by volost' and parishes (both Orthodox and Catholic) The final work to determine the exact number of villages is still to be carried out. The estimated number is 2,000-3,000 settlements. The research strategy is described in Bukhovets, Sotsial'nye konflicty, pp. 79-89.

I I. Ibid. pp. 363-367.

I2. Russian State Historic Archive (St Petersburg) (RGIA) Fund I 278-The State Duma, op. I (Ist convene), d. 29I, 1. 22I-227.

I3. RGIA Fund I4I 2 - His Royal Majesty's Office for the Registration of Petitions Addressed to his Royal Majesty, op. 242, d. I196, 1. I, d. I 197, 1. I.

I4. Ibid., d. 6is l. I-2. 
Apart from the sixty-nine documents which touch upon Jewishness directly, there is another group of petitions which mention this topic in an indirect way. This is true for a group of nine documents with a conservative political orientation. ${ }^{\text {Is }}$ These are characterized by the use of terms such as "aliens", and "heterodox", in an obviously negative sense, combined with the use of phrases such as "we, ethnic Russians", "we, ethnic Byelorussians" or "we, ethnic Russian peasants". For instance, the parishioners of the church of St Nicholas in the village of Tcherkessy (Disnen district, Vilno region), in their telegram dated October I906, appeal to Emperor Nicholas II in Tsarskoye Selo "not to let us, Ethnic Russians, and our Orthodox Church die in this western part of the Empire under the pressure of the aliens" ${ }^{16}$ We can safely assume that the authors of this group of documents included Jews when they referred to "aliens".

The other extreme is represented by fifteen petitions of a radical, antigovernmental orientation. In these documents, the words "Jews" or "Jewish" are not directly present either, but the opinion is voiced that equal rights should be granted in Russia to all citizens, regardless of nationality and religion. ${ }^{17}$ "Our plea to you, Your Majesty", wrote the peasants of the Selyshshe volost in the district of Gorodok, region of Vibetsk, "is both for ourselves and for the others: make us equal before the law. Let there be no people in your great country, who are deprived of all rights by birth." ${ }^{8} 8$ This position or demand makes these petitions comparable to the sixty-nine which do mention Jewishness explicitly. There are many more petitions which directly or indirectly express ideas in support of equality, but, to meet the strict conditions laid down for our analysis, only these fifteen will be included in the group of documents discussed.

If we add nine conservative and fifteen left-wing and liberal petitions which mention Jewishness implicitly to the sixty-nine which do so explicitly, the total number grows to ninety-three documents. They come from thirty-one Byelorussian districts, were written by the peasants of

I 5. Ibid., Fund 91 - Free Economic Society; op. I, d. 837, 1. 83-84; Fund I 282 - The Office of the Minister of the Interior, op. 3, d. 684, 1. 59; Fund I291 - The Zemsky Department of the Ministry of the Interior op. I 22- I 906, d. I 5 , l. I I 7; d. 24, 1. 225 , 237-238, d. 27, l. I I 7, d. 62, 1. 96; Fund 1327 - The Special Office for the Elections to the State Duma and the State Council of Russia, op. 2, d. 59, 1. 17, 25, 37.

16. Ibid., f. I 327 , op. 2, d. $59,1.37$.

17. The State Archive of the Russian Federation (Moscow) (GARF) Fund I02 - The Police Department - The Special Department, DP-00, I905, d. 999, part 45, 1. 200-202, RGIA f. 9I, op. I, d. 837, 1. 19-20, 33-34, 40-4I, 45, 96, 99, 109, 172-173; Fund 396 - Department of State Land Properties, op. 3, d. 42, 1. 28; Fund I 276 - The Council of Ministers, op. I, d. 22, 1. I 58 - I 59; F. I 278 , op. I (Ist convene) d. 236, 1. I33-I34; d. 270, 1. 50-52; (2nd convene), d. 759, 1. I67; Vtoroy period revolutii. 1906-1907 (Moscow, 1963), pp. 507-510.

I8. RGIA f. I276, op. I, d. 22, 1. I59. 
ninety-eight villages, three agricultural cooperatives, two peasants' groups and two peasants' organizations, twenty-nine rural communities (which in Byelorussia on average counted two to three villages), eight volosts and six parishes.

\section{THE VARIETIES OF ATTITUDES}

Let us now consider the typology of the sixty-nine documents which refer to Jewishness directly, and see precisely which attitudes are reflected. It is of particular importance to recognize the qualitative differences in the various attitudes. As the total group of documents is relatively small, we shall have only a few petitions to represent some of the attitudes. However, it must be kept in mind that these small numbers probably represent the attitudes of large groups over the whole of Russia. Studying the documents allows us to single out seven different types of attitudes. They are described here from "left to right".

The first type is found in five documents. Their authors see Jews as a social and ethno-confessional group to which they clearly have a positive and sympathetic attitude. ${ }^{19}$ Thus the peasants of Monastyrshsina, a small village in the Mstislav district of the Mogilyev region, describe the local Jews as their direct competitors, but also mention with sympathy that they "do not possess land and also need to feed their families". ${ }^{20}$ In late June 1906, the peasants of Lazorevtsy, a village in the Novo-Bykhove volost of the Mstislav district in the Mogilyev region, sent a petition to a left-wing member of the State Duma, Bouslov. In it they state that the forced concentration of Jews ("landless and jobless people") in the western regions of the Empire is harming both the Jews and the local population. The recommend eliminating the Jewish Pale and granting Jews freedom of movement. They expect that, in that case, Jews will not have to "exploit people with a low level of knowledge", but "will be able to take up their own businesses". ${ }^{21}$ A petition of a group of peasants' representatives of the Grodno district to the State Duma is of great interest. These peasants had struck a deal with urban Jewish representatives to employ a mutually advantageous tactic at the 1907 elections for the second Duma. This enraged the city authorities, who wanted to promote a deal between peasants and the district's landowners. The peasants described the pressure by the Orthodox clergy and the police to accept the coalition with the

19. Ibid., f. 91, op. I, d. 838.1. го, 35-37; f. г 278, op. I (2nd convene); d. 750, sh. 98-100, f. I 291, op. $63-$ I907, d. I, l. 28 I-282, f. I 327 , op. I (2nd convene), d. Io, 1. 63.

20. Ibid., f. 91, op. I, d. 837 , l. го.

21. Ibid., 1. 37. 
landowners as an "act of violence against our personality, consciousness and religious feelings". ${ }^{22}$

The second group is formed by eight documents, the authors of which use the term "Jew" only to qualify a social and ethnoconfessional group. Their attitude is purely neutral. ${ }^{23}$ For example, in November I905, the residents of Skilled', a small settlement in the Grodno district, in their petition to the Tsar, write that their pasture, small as it is, is a "mutual property with all Jews and other inhabitants of that place". ${ }^{24}$ In October 1906, in a lengthy appeal to the Minister of the Interior of the Russian Empire, the peasants of Tourov, a small settlement in the Mozyr district of the Minsk region, mention in passing that they "buy manure from the Jews". ${ }^{25}$ And the parishioners of the Orthodox parish of Meleshkovici in the diocese of Minsk, in a complaint about their local priest addressed to the Holy Synod, accuse him, among other things, of having sold illegally materials designated for the construction of the Church "to local peasants and a Jew Yeleska Rozenman". ${ }^{6}$

The third group of petitions is the most numerous one. It includes twenty-three documents, or one-third of our group of sixty-nine. They use the designation "Jew" or "Jewish" as a synonym for "rich". ${ }^{27}$ The peasants of Dragoun, a rural community in the Bykhov district of the Mogilyev region, for example, write that their own hayfields are not enough and they have to "spend all we have buying from the Jewish leaseholders". ${ }^{28}$ The residents of the Yakoubovitchi and Krasnoye settlements of the Bershtovo volost, in the Grodno district and region, wrote an appeal to the first Duma on 4 December 1905, complaining of the high prices of timber. As a result, so they wrote, only "merchants and Jews can afford to buy it while a poor peasant $[\ldots]$ has to buy from a Jew and pay big money". ${ }^{29}$ It is obvious that the attitude in all these documents is hostile, but it is not verbalized as antiSemitic hostility. To the authors of the petitions, it is not the nationality or the confession that matters, but the fact that the specific Jews who are

22. Ibid., f. I327, op. I (2nd convene), d. Iо, 1. 63.

23. Ibid., f. 91, op. I, d. 837, 1. I I2; f. 796, op. г88, d. 7185, 1. I; f. I291, op. 63-1906, d. 228, 1. 269-276, 319-320; f. I4I2, op. 242, d. 61 5, 1. I; d. 625, 1. I-3; d. I I 50, 1. 2-3; d. I I 59, 1. I-5.

24. Ibid., f. I4I 2 , op. 242 , d. 625 l. I.

25. Ibid., f. I 291, op. 63-1906, d. 228, 1. 274.

26. Ibid., Fund 796 - The Secretariat of the Synod, op. i88, d 7 I 85 , l. I.

27. The State Historic Archive of Lithuania (GIA Litvi), f. 445, op. I, d. 4483, 1. 76; RGIA, f. 9I, op. I, d.. 837, l. I5-I6, I7-I8, 42, 62-63, 64, I00, I03, I30-I32, I61, I66; f. I278, op. I (Ist. convene), d. 244, 1. 285-286; d. 268, 1. 224-225; d. 277, 1. 59-60; d. 282, 1. 49-50; d. 29I, 1. 2 I 22 I 3 ; (2nd. convene), d. 779, 1. 74-75, 76-77, 79-8 I; d. 785, 1. 44-46, f. I291, op. 63-1905, d. 450 , 1. 256; op. 63-1906, d. 230, 1. 400-401; op. 73-1906, d. 724, 1. 356, 359; f. I4I 2, op. 242, d. I I95, 1. I; d. I197, l. I.

28. RGIA, f. 9I, jg. I, d. $837,1.64$.

29. Ibid., f. I 278 , op. I (Ist convene ) d. $277,1.59$. 
mentioned are rich. To quote another example from this group, the residents of Kolotovo, a village in the Mstislav district in the region of Mogilyev, in their report to the Duma, accuse the forester of having sold "the woods to the Jews which provided profit both for the Jews and for himself"..$^{\circ}$

The fourth is one of the smallest, with only four documents. They express a moderate negative attitude towards Jews. ${ }^{3}{ }^{\text {I }}$ For example, the parishioners of the Kokhanovitcy church in the Drissi district of the Vitebsk region write, in their appeal to the Holy Synod, that local Jews use the indecent behaviour of a local priest to mock the local Orthodox residents. ${ }^{32}$ The residents of four villages - Zapolye, Lesnaya, Zjouky and Krasnaya in the Korelitchi volost, in the district of Novogroud in the Minsk region - sent an appeal to the Chairman of the Duma, dated 2 I June 1906, on their lawsuit with their landlord, the Count of Pouttkamer, about a piece of land. Several courts had decided in favour of the count, but, according to the peasants, this was because the two witnesses of the count "were the Jews who had and still have close contacts with the count". 33 The negative attitude audible in these petitions is limited to the action of the particular Jews mentioned. In the last case, the dependence of the two witnesses on the count is mentioned to explain their behaviour.

The fifth group comprises fourteen petitions which show a clearly hostile attitude towards Jews. ${ }^{34}$ But again, in this category, their complaints are concrete and specific, without any hint of anti-Semitic ideologies. The accusations levelled against Jews never exceed local boundaries. For example, the residents of Milashevo village, in the volost of Drouya (Disna district, Vilno region), in their petition of June 1907 to the Holy Senate, write that the Jews Stoutchinsky and Taubman, having acquired the big Drouya estate, "began to exploit the population of a huge region". 35 Furthermore, in thirteen of these fourteen cases the word "Jew" is a synonym to the words "rich", "successful", or "tricky competitor", who can come to an understanding not only with the local authorities, but also with the landlords, can use the elected government of rural communities, or can seduce the peasants. Thus, the residents of the three

\footnotetext{
30. Ibid., d. $244,1.285$.

31. Ibid., f. 91 op. I, d. 837, 1. I 54-155; f. 796, op. I87, d. 737, 1. I-2, op. I88, d. 721 2, 1. I-2;

f. I 278 , op. I (ist convene) d. 250 , 1. I $54-155$.

32. Ibid., f. 796, op. 187, d. 737, 1. г; op. 188, 1. 7212 , 1. I.

33. Ibid., f. I 278 , op. I (Ist convene), d. 250 , 1. I 55 .

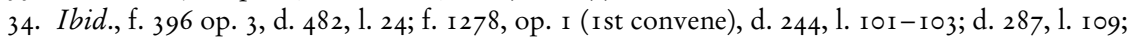
d. 293, l. I0-I 52; (2nd convene) d. 799, 1. I 5-I6, I73-I75; f. I327, op. 2, d. 59, 1. I 8; Fund I 344 The Second (Peasant) Department of the Senate, op. 203, d. 953. 1. 2-3; f. I4I 2, op. 242, d. 6I 4 , 1. 2-3; d. 1077, 1. 2-5; d. II 25, 1. I8-2 I, d. I I58, 1. 2-3; d. I207 l. 2-3; d. I222, 1. I-2.

35. Ibid., f. 1344, op. d. 953 , 1. 2.
} 
rural communities if the Narovlyany volost in the Retchitsa district of the Minsk region insisted in their petition of March I906, that from the Jewish landholders they "often hear bad news and they are also guilty of robbery". ${ }^{36}$ The telegram to the Chairman of the first Duma signed by the peasants of the village of Thchernyany in the distric of Brest accused the Jews, Vinograd and Liftshits, the de facto owners of the neighbouring estate, of bribing the court and grasping the ownership of the local pasture. 37

The sixth type is represented by eleven petitions. These offer a theoretical basis for legal and political discrimination against Jews. ${ }^{3}$ Even so, within this group the arguments sometimes have a liberal ring to them. The peasants of the Minsk region and the urban lower-middle class inhabitants of the Retchitsa district write: "we believe that the time is not yet ripe to give equal rights to Jews because we are not educated enough as to coexist peacefully with Jews who are mentally developed and well educated in all spheres". ${ }^{39}$

The other petitions of this type taken together make up a sort of "saga" about the struggle of peasants with Jews for land and forests. The petitions call upon the authorities to introduce limitations for Jews in the fields of economy, law, and culture. Take, for example, the resolution of the united rural assembly of the Zabolotye and Gautzevitchi villages of the Soly volost, in the Oshmyany district of Vilno region, of is December I905, asking "to protect the local population from rich private owners and merchants, especially Jews, and not give the latter any privileges as compared to Christians". ${ }^{\circ}$ The peasants of the village Dvoretz, in the volost Tikhinitchi, in the Rogatchev district of the Mogilyev region, insisted that they had a "moral right" to possess the estate of the same name (Dvoretz) as they used to be serfs on this estate. They were deeply convinced that the current leaseholder Josil' Slavin "as a Jew" had no right to hold the lease at all. ${ }^{4}$ The residents of Garvel' village in the volost Zaslavl', in the district of Minsk, who petitioned the first Duma in May I 906, argued that Jews could be allowed to lease land, but only small plots. They should, however, be forbidden to buy land or trade horses as "they are all connected with thieves". ${ }^{2}$

The ideology of integral anti-Semitism is represented by a group of four

36. Ibid., f. I412, op. 242, d. I I $58,1.2$.

37. Ibid., f. I 278 , op. I (Ist convene), d. 287 , 1. Iо9.

38. Ibid., f. 91, op. I, d. 837, 1. I 52-1 53; f. I 278, op. I (Ist convene), d. 264, 1. 17-20; d. 288,

1. $253-256$; (2nd convene), d. 756 , 1. 26-27; d. 757, l. I4I7; d. 787, 1. 342-34; f. I4I 2, op. 242, d.

I 34, 1.8-IO, I3-I6, I9-22, $25-28$; d.I 225, 1. 2-3.

39. Ibid., f. I 278 , op. I (2nd convene); d. $787,1.342$.

40. Ibid., f. I4I 2, op. 242, d. I34, l. 2 I.

4I. Ibid., d. I225, l. 3 .

42. Ibid., f. I 278 , op. I, (Ist convene), d. $288,1.256$. 
petitions that make up the seventh type. Their authors do not care whether the Jews are rich or poor, left- or right-oriented. They consider Jews to be "parasitic aliens" who seek to "destroy the state", to establish a republican government, and to elect Grishka Roubinstain or Moska Vinaver as president. ${ }^{43}$ "If they do not like Russia, let them go and live in any Republic where they will have the right to rule the country", and "down with the pro-Jewish and heterodox Duma", as representatives of "For the Faith, the Tsar and the Fatherland", a circle of peasants in the Grodn'o region, claiming to have I, 256 members, wrote on 8 July $1906 .{ }^{44}$ The petition the elected representatives of the peasants of the village of Yanovo in the Stolbouny volost of the Gomel' district sent, in September I905, to the chairman of the Special Council is characterized by extreme intolerance. It characterizes the whole revolutionary movement as a conspiracy of "the criminal Jewish Bund [...] that excites the illiterate masses everywhere to grasp power". The authors of the petition call upon the government to deny to Jews the right to lease land, as "the majority of the estates is now in the hands of Jews who [...] exploit the people so severely that even serfdom seems to be Heaven". ${ }^{5}$ The petition of Polyanovitchi village in the Novo-Bykhov volost, in the region of Mogilyev, reads that Jews "should not be allowed to work in the field of education and should be sent to live in Palestine so as not to disturb and provoke Russia". ${ }^{6}$ Anti-Semitism here is but a form of hatred of everything "alien and heterodox", or is comparable to a negative attitude "to the Poles, the Tartars and to Finland". 47 The peasants of "For the Faith, the Tsar and the Fatherland", and of Polyanovitchi village, also oppose the equality of women, and the last document condemns intellectuals as "mean, villainous and bad for peasants".

43. Ibid., f. 91, op. I, d. 837, 1. 23-29; f. 396, op. 3, d. I I17, 1. I 59-160; Fund I 2 I 2 - A Special Council on the Measures to Support Peasants' Land ownership, op. I, d. 2, 1. 446-447; f. I 278 , op. I, (Ist convene), d. I 45, 1. 239-240. Grishka Roubinstain: in all probability the authors mean Dmitry L'vovich Roubinshtain, a Jewish public activist, (1876-?), who was later close to Grigory Raspoutin. After Raspoutin's death in 1916 he was arrested and accused of speculations. After he was released he immigrated and his further biography - even the date of his death - is unknown. By Moska Vinaver the authors mean Maksim Moiseevich Vinaver (I 862/63-I926), a well-known Jewish lawyer and deputy of the State Duma of Russia. A leader of the Cadet party, he was a theoretician of liberalism and founded several organizations to acquire civil rights for Jews in Russia.

44. In a petition addressed to Mouromtsev, the chairman of the State Duma, Count Geiden, a Duma Deputy, and Tchemodourov, a State Council member; ibid., f. I 278, op. I (Ist convene), d. $145,1.238-240$.

45. Ibid, f. I 2 I 2, op. I, d. 2, 1. 446-447.

46. Ibid., f. 91, op. I, d. 837, l. 29.

47. The second quotation is from the petition of Polyanovitchi village quoted before; ibid., f. 9I, op. I, d. $837,1.2526$. 
The core image of a Jew as understood by the authors of the sixty-nine petitions was thus one of a "rich", "wealthy", or "successful" person. In forty-nine documents (7I per cent) out of the sixty-nine, Jews are leaseholders, merchants, timer producers, or top managers. In this context, the word "Jew" is used only in the documents with a negative connotation, the petitions of groups $4-7$. Only eight out of the thirty-three petitions in these groups fail to associate "Jewish" with "rich". In the petitions of the complementary and neutral groups, only in one case can the word "Jew" be interpreted as meaning rich. Given the real situation of most of the Jewish population, the petitions which equate "Jewish" and "rich" cannot be seen as an actual representative image of Jews as a social and ethnoconfessional community.

But even in the petitions which associate Jews exclusively with the rich and wealthy, they are not the prime target for invective. In seventeen out of the thirty-three petitions concerned, the main targets for accusation are landlords. In three other documents the priests and hierarchs of the Orthodox Church are criticized, and in two more, accusations are levelled as much against the separatist attempts of Poland, Lithuania, and other parts of the Empire as against Jews. In other petitions, accusations are made as much against landlords, or an Orthodox monastery, as against Jews. Only in eight out of the thirty-three documents in the most negative groups, are Jews the main target for the peasants' invectives. In this context, it is worthwhile to consider again the third group of documents, in which the words "Jew" and "Jewish" are synonyms for "rich and "wealthy". In twenty out of twenty-three documents of this type, the main target of criticism is the landlords, and, in two other cases, the main criticism is directed against civil servants.

As was mentioned before, we can also take into consideration fifteen petitions for equality and nine petitions against aliens, which are concerned with Jewishness implicitly. This brings the total of documents in our analysis up to ninety-three. Of these, twenty documents (fifteen of the "for equality" set and five petitions in the first group), which together make up 2I.5 per cent of the total, show a positive attitude towards Jews. The eight documents in the second group (8.6 per cent of the total) have a neutral attitude. The authors of the twenty-three petitions in the third group (24.7 per cent) show an indifferent attitude. The small fourth group exhibits a moderately negative attitude towards Jews. The petitions of the fifth, sixth, and seventh groups, and of the set against aliens, demonstrate an openly negative attitude. No more than thirty-eight documents (40.9 per cent of the total) fall within these groups.

Compared with much historical research in this slippery field, which is so full of stereotypes and prejudices, these results are relatively clear. Contrary to what would have been expected on the basis of the existing literature, the general level of anti-Semitic feeling, as expressed in petitions, 
is low. Even in the petitions that voice a position on Jews, only 45.2 per cent (forty-two documents) are moderately or openly negative. And this result was obtained in the part of the Russian Empire with the highest density of Jews. Even the negative attitudes are rather moderate. AntiJewish feelings crop up in the shadow of a much stronger negative attitude toward landlords. Among the aliens mentioned in these petitions, together with Jews, as those who cannot be treated as one of "ours", are also Catholics, Polish, Lithuanians and Latvians..$^{8}$ For example, the Orthodox peasants of the village of Tserkoviye of the Merkoulovitchy volost, in the district of Rogatchev in the Mogilyev region, when pressing charges against a certain Shklyarevitch, among other arguments mentioned the fact that he was an Old Believer. ${ }^{49}$ In the same way, when the opposite side in a dispute happened to be Jewish, this fact was mentioned to "strengthen" the position of the accusing party.

\section{THE SILENT MAJORITY}

The high concentration of Jews among the Byelorussian population in the epoch under analysis would seem to offer a potential for anti-Jewish feelings. The analysis shows that this potential was not realized. Of the petitions identified in the course of this research project, 86 per cent do not refer to Jews. How do we interpret this? It cannot be the case that the nature of the source did not allow Jews to be mentioned. As we saw, hundreds of subjects were touched upon. The documents represent all thirty-eight districts of Byelorussia without exception, and in two-thirds of the cases each district is represented by dozens of villages. The petitioners, coming from all parts of Byelorussia, must have noticed the strong presence of Jews in most spheres of life, and especially among those engaged in intellectual activities, merchants, and the urban population..$^{\circ}$ If they must have been aware of the Jewish presence, this was clearly not very important for the majority of those writing petitions. We can thus use the sources as an argumentum ex silentio: the attitude to Jews of the authors of petitions that do not mention Jewishness was probably indifferent or neutral.

There are some additional arguments for this position. Of the whole collection of 662 petitions, 54 contain some information about the identity

48. RGIA, f. 396, op. 4, d. I3, 1. 200; f. I 278, op. I (Ist convene), d. I45, 1. 240; f. I282, op. 3 , d. 684 , 1. 59; f. I291, op. 63-1905, d. 450, 1. 233; op. I22-I 906, d. 62, 1. 96; f. I 327, op. 2, d. 59, 1. I7, I 8,25 , 37; f. I4I2, op. 242 , d. I I 58 , 1. 2; d. I225, l. 3 etc.

49. Ibid., f. I 278 , op. I, (Ist convene), d. 279, 1. 64.

50. Shybeka, Garady Belarusi p. 265; P.A. Grigorieva and M.Ju. Martynova, "Mezhetnicheskie otnosheniya I natsional'naja politika Belorussii”, Novye slavyanskie diaspory (Moscow 1996), p. I42; V.P. Panjutich Social'no-economicheskoe razvitie belorusskoj derevni v I86I-I 900 gg. (Minsk, 1990), p. 36r. 
of the people who wrote them for the illiterate peasants ("from their words" as the documents put it), edited the final version and, in some cases, signed the documents for those unable to do so. In I 8 of the 54 cases, the scribes were local, or - more rarely - immigrant Jews. ${ }^{5 \mathrm{I}}$ Jewish scribes were not only employed when a left-wing petition was to be written. Only three of the petitions put down by Jews were of an antigovernmental orientation, two more were apolitical, and the other thirteen were quite pro-tzarist. This is direct proof to the fact that when the peasants selected the scribes and editors for their petitions, they were not influenced by religious and racial prejudices.

Further support for the proposed interpretation of the silence of the majority of the petitions can be gleaned from the historic context. The high density of the Jewish population in Byelorussia went hand in hand with a high level of religious and ethnic tolerance of the population, for Eastern Europe, including a tolerance of Jews. Anti-Semitism was mild, compared with other regions of the Jewish Pale, not very aggressive and not uncompromising..$^{22}$ This seems to be continuous factor in Byelorussian history: it is true for the periods of the Great Lithuanian Principality and the Retch Pospolitaya periods as well as for modern history, especially for such critical periods as those of the pogroms in the Russian Empire in the second half of the nineteenth and the early twentieth centuries, the 1905I907 Revolution, the October Revolution, the Civil War, the Nazi occupation of 1941-1944, the disintegration of the Soviet Union, and the establishment of the independent Byelorussian state. There may be a connection here with the national consciousness of Byelorussians, which is not very manifest and not intensely held. This holds true to the present day.

In conclusion, we can state that we found both nonverbalized and verbalized traces of attitudes towards Jews in petitions, and that these have allowed us to map attitudes towards Jews better than before. To sum up: of the petitions that explicitly mention Jews, less than half do so in a clearly negative way. This negative attitude is overshadowed by a stronger negative attitude towards landlords. Even in the turbulent period of the I905-I907 Revolution, Orthodox Byelorussians were much more tolerant

5I. The Central State Historic Archive of the Ukraine (Kiev) (CGIA of Ukraine), Fund 317 The District Court, op. I, d. 3657 , 1. I-2; Fund 3 I 8 - The District Court Procurator. op. I, d. 891, 1. I 9; RGIA f. 396, op. 3, d. 488, 1. 268; f. I291, op. 63-1905, d. 450, 1. 235; op. I 22-1905,

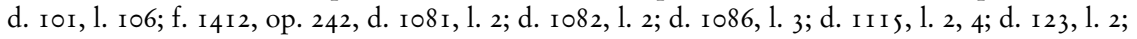
d. II 30 , 1. 2; d. II 32 , 1. 2; d. II 38 , 1. 4; d. II 40, 1. 2, 5; d. II 80 , 1. 2 .

52. The main results of this study can be found in O.G. Bukhovets "Evrei v narodnom soznanii (opyt izucheniya na primere Belorussii v $20 \mathrm{v}$.)", pravo na svobody. The papers of an international conference 29-30 October 1998, "Istoriya bor'by za svobody v I7-20 vv." (k 50letiju odobreniya General'noj Assambleej OON Vseobtshej deklaratsii prav cheloveka) (Moscow, 2000), pp. 93-99, I02-104. 
of Jews than of landlords with whom they shared their ethnic and religious background. The variety of attitudes that come out of the petitions is striking. They force us to adjust radically previous ideas on feelings about Jews and Jewishness in early twentieth-century Byelorussia. 